\title{
Impact of solar radiation on the biological removal of dimethylsulfoniopropionate and dimethylsulfide in marine surface waters
}

\author{
Doris Slezak $^{1, *}$, Albert Brugger ${ }^{1}$, Gerhard J. Herndl ${ }^{2}$ \\ ${ }^{1}$ Dept of Marine Biology, Institute of Ecology and Conservation Biology, University of Vienna, Althanstrasse 14, \\ 1090 Vienna, Austria \\ ${ }^{2}$ Dept of Biological Oceanography, Netherlands Institute for Sea Research, PO Box 59, 1797 AB Den Burg, Texel, \\ The Netherlands
}

\begin{abstract}
The effect of natural surface solar radiation on the biological removal of dimethylsulfoniopropionate (DMSP) and dimethylsulfide (DMS) was determined and compared to the photochemical removal of DMSP and DMS. Natural bacterial assemblages (0.8 $\mu$ m filtered seawater) from the northern Adriatic Sea and the coastal North Sea were exposed to surface solar radiation and incubated in the dark; the DMSP and DMS concentrations were measured concurrently. Photochemical removal rates were determined in $0.2 \mu \mathrm{m}$ filtered seawater. Biological removal of DMSP in the light was $62 \pm 14 \%$ lower than the biological removal rate obtained in the dark. High spatial and temporal variability in the biological removal rates was observed for the dark treatments, as well as for its sensivity to solar radiation, with rates for light treatments varying from 29 to $81 \%$ of those in the dark. The DMSP concentration above which no further increase of the biological DMSP removal rate was observed was substantially lower in the light treatments $(\sim 30 \mathrm{nM})$ than in the dark treatments (>80 nM). UV-B radiation only accounted for a minor inhibitory effect $(\sim 15 \%$ of total inhibition), whereas UV-A and PAR (photosynthetically active radiation) both contributed $\sim 42 \%$ of total inhibition. Biological DMS removal under solar radiation was only $\sim 40 \pm 14 \%$ of the biological DMS removal in the dark. Under surface solar radiation, photochemical removal was always higher than the dark biological removal. Our results indicate therefore, that the DMSP and DMS dynamics in the oceanic surface waters are severely influenced by solar radiation due to the partial inhibition of the microbial consortia responsible for DMSP and DMS turnover.
\end{abstract}

KEY WORDS: DMSP · DMS · Ultraviolet (UV) radiation · Bacteria · Biological removal · Photochemical alteration

Resale or republication not permitted without written consent of the publisher

\section{INTRODUCTION}

Stratospheric ozone depletion causes an increase in ultraviolet-B (UV-B, 280 to $320 \mathrm{~nm}$ ) radiation over polar regions during spring when the polar vortex is breaking up (Crutzen 1992, Smith et al. 1992, Kerr \& McElroy 1993). This increase in UV-B radiation, however, is not restricted to polar regions but is also detectable in temperate zones (Blumthaler \& Ambach

${ }^{*}$ Present address: Institute of Limnology, Austrian Academy of Sciences, Mondseestrasse 9, 5310 Mondsee, Austria.

E-mail: doris.slezak@oeaw.ac.at
1990). UV-B radiation reaching the earth's surface also penetrates into aquatic systems. Recent studies have shown that UV-B radiation penetrates much deeper into the oceanic water column than previously thought (Gieskes \& Kraay 1990, Obernosterer et al. 2001). Therefore, non-motile organisms and dissolved organic matter (DOM) are exposed to high levels of UV$B$ radiation in the oceanic surface layers due to diurnal stratification of the surface layers down to $40-50 \mathrm{~m}$ depth (Obernosterer et al. 2001).

DNA replication and protein synthesis of bacterioplankton are reduced by 40 to $70 \%$ under exposure to solar radiation (Herndl et al. 1993, Müller-Niklas et al. 
1995, Sommaruga et al. 1997), and direct DNA damage on a cellular base has been reported (Jeffrey et al. 1996, Lyons et al. 1998). Besides the direct effects of UV radiation on organisms, it also affects organisms indirectly by changing their chemical environment (Palenik et al. 1991). There is increasing evidence, that UV radiation alters DOM in different ways by transforming refractory DOM into more labile forms and vice versa (Benner \& Biddanda 1998, Tranvik \& Kokalj 1998, Obernosterer et al. 1999, Pausz \& Herndl 1999). Additionally, a part of the dissolved organic carbon (DOC) is photo-oxidized into $\mathrm{CO}_{2}$ and $\mathrm{CO}$ (Mopper et al. 1991, Graneli et al. 1995). Moran \& Zepp (1997) estimated that photochemical degradation of DOM into low molecular weight organic compounds and dissolved inorganic carbon amounts to $2-3 \%$ of the oceanic DOC pool. Moreover, the production of photosensitizers can lead to photochemical alteration of DOM compounds which do not absorb UV radiation (Zafiriou et al. 1984, Cooper \& Lean 1989). One example of photosensitizer activity is the photochemical alteration of dimethylsulfide (DMS) (Kieber et al. 1996). It has been shown that the rate of photochemical alteration of DMS strongly depends, among other factors, on the concentration of DOC (Brugger et al. 1998).

The production of DMS in the euphotic zone represents the main source of the biogenic sulfur flux from the oceans to the atmosphere (Barnard et al. 1982, Andreae \& Raemdonck 1983, Andreae 1990). In the upper layers of the ocean, DMS is primarily formed via the enzymatic cleavage of dimethylsulfoniopropionate (DMSP) (Cantoni \& Anderson 1956, Kiene 1990, Ledyard \& Dacey 1994), an organic osmolyte (Vairavamurthy et al. 1985) produced by certain phytoplankton species (Keller et al. 1989a,b). The main pathways of the removal of DMS from the upper oceanic layers are biological consumption by bacteria (Kiene \& Bates 1990), biological oxidation (Liss et al. 1997), photochemical transformation (Kieber et al. 1996, Brugger et al. 1998), sedimentation (Lee \& Wakeham 1992, Osinga et al. 1996) and evaporation (Andreae \& Raemdonck 1983, Nguyen et al. 1983).

In the troposphere, DMS is oxidized to sulfate and methane sulfonate, both contributing to the pool of sub- $\mu \mathrm{m}$ aerosols and cloud condensation nuclei which are involved in cloud albedo and backscatter of incoming solar radiation hence affecting the global climate (Charlson et al. 1987, Ayers et al. 1991, Prospero et al. 1991, Berresheim 1993). The flux of DMS to the atmosphere is strongly dependent on the concentration of DMS in the surface layer of the ocean (Liss 1973).

As pointed out by Zepp et al. (1995), increased solar UV radiation might influence the oceanic sulfur cycle due to altered dynamics of production and turnover of DMSP and DMS. There are only a few studies on the photochemical transformation of DMS (Brimblecombe \& Shooter 1986, Kieber et al. 1996, Brugger et al. 1998) and on the role of microorganisms on these dynamics as influenced by UV radiation (Hefu \& Kirst 1997, Sakka et al. 1997). Hefu \& Kirst (1997) found that artificial radiation including UV-B caused an increase in the conversion rate of DMSP to DMS compared to treatments without UV-B, suggesting a photochemical cleavage of DMSP.

The aim of this study was to determine the role of surface solar radiation levels on the degradation of DMSP and DMS mediated by bacteria. Furthermore, biological removal was compared to photochemical alteration of DMSP and DMS in order to assess the relative importance of these 2 processes in the upper layers of coastal waters.

\section{MATERIAL AND METHODS}

Sampling sites. Surface water was collected in acidrinsed carboys or buckets from the coastal northern Adriatic Sea about $5 \mathrm{~km}$ off the coast of Ancona $\left(43^{\circ} 33^{\prime} \mathrm{N}, 13^{\circ} 9^{\prime} \mathrm{E}\right.$, Italy) and from the coastal North Sea $\left(52^{\circ} 59^{\prime} \mathrm{N}, 4^{\circ} 50^{\prime} \mathrm{E}\right.$, The Netherlands). Water from the coastal North Sea was collected at high tide from the NIOZ pier in the North Sea and from a boat in the Adriatic Sea. In most experiments, samples were processed immediately. However, in the case of the coastal North Sea when water was collected in the evening, Whatman GF/C filtered samples were stored at in situ temperature overnight before starting the experiments the next morning. Storage effects are considered to be low, since almost all the phytoplankton were retained by the GF/C filter. The composition of the bacterial community might, however, experience some storageinduced changes.

Experimental setup. In order to determine the bacterial removal of DMSP and/or DMS, natural water samples were filtered through $0.8 \mu \mathrm{m}$ polycarbonate filters (Millipore) to remove most of the non-bacterial organisms. For the determination of free DMSP lyase activity and the photochemical alteration of DMSP and DMS, $0.2 \mu \mathrm{m}$ filtered samples (polycarbonate filters, Millipore) served as a control. Experiments were performed either with natural DMSP and DMS concentrations or with elevated concentrations by adding DMSP or DMS up to a final concentration of $\sim 50 \mathrm{nM}$ and gently inverting the samples several times before taking subsamples to determine the initial concentrations. The unamended and DMSP- and DMSamended samples were filled gently into quartz Erlenmeyer flasks $(100 \mathrm{ml})$ and sealed with glass stoppers without headspace. For sampling over time, 1 to 2 flasks were sacrificed at each time point to avoid the 
formation of headspace via subsampling. Half of the bottles were wrapped with aluminum foil to serve as dark controls. The quartz Erlenmeyer flasks were incubated outdoors under natural surface solar radiation during cloudless days at in situ temperature in a water bath. As an example, on 10 July 1997 radiation intensity for the incubation period was 54 and $785 \mathrm{~kJ}$ $\mathrm{m}^{-2}$ for UV-B and UV-A and $48 \mathrm{E} \mathrm{m}^{-2}$ for PAR (photosynthetically active radiation), respectively (measured with a biospherical PUV-510 radiometer, see also Obernosterer \& Herndl 2000).

Effect of solar radiation on the kinetics of bacterial DMSP removal. Time course experiments were conducted at in situ DMSP concentrations to study the kinetics of the biological DMSP removal in the presence of surface levels of natural solar radiation. To determine the potential removal rate, experiments were performed after adding DMSP ( $50 \mathrm{nM}$ final concentration) to $0.8 \mu \mathrm{m}$ filtered seawater (Kiene 1996b). Incubations started between 09:30 and 10:30 h and lasted for 6 to $7 \mathrm{~h}$ to cover almost the entire period of UV radiation. In 30 to $120 \mathrm{~min}$ intervals, Erlenmeyer flasks incubated in the dark or exposed to solar radiation were brought to the lab and processed for further analysis as described below. Incubations were made in duplicate (time interval $>1 \mathrm{~h}$ ) or in single bottles (time interval $=30$ to $60 \mathrm{~min}$ ). In 4 out of 11 experiments conducted to determine the kinetics of biological DMSP removal, the DMS concentrations were also measured. The bacterial DMS removal in the dark and the DMS removal under solar radiation were compared with the photochemical removal of DMS under solar radiation. Seawater filtered through $0.2 \mu \mathrm{m}$ filters and incubated in the dark served as controls for free DMSP lyase activity.

Effect of different DMSP concentrations on the inhibition of DMSP removal by solar radiation. In order to test whether the inhibitory effects of UV radiation on DMSP removal are dependent on the initial DMSP concentration, experiments were performed with different DMSP additions. After filtering the water through 0.8 or $0.2 \mu \mathrm{m}$ polycarbonate filters, $250 \mathrm{ml}$ glass bottles were filled and DMSP was added to the different flasks at 5 different concentrations ranging from 3 to $93 \mathrm{nM}$ final concentration. After gently mixing, the flasks were subsampled for $t_{0}$ measurements and transferred into quartz Erlenmeyer flasks and incubated outdoors under surface solar radiation for $6 \mathrm{~h}$. Incubations were always made in duplicate; the $0.2 \mu \mathrm{m}$ filtered samples served as a control.

Influence of different solar radiation regimes on the DMSP removal. To investigate the effects of various ranges of the solar radiation spectrum, samples in quartz Erlenmeyer flasks were exposed to 4 different radiation regimes: PAR (400 to $700 \mathrm{~nm}$; wavelengths
$<400 \mathrm{~nm}$ were cut off by acrylic glass; XT 20013, $3 \mathrm{~mm}$, Röhm, Germany), PAR+UV-A (wavelengths $<320 \mathrm{~nm}$ were cut off with Mylar D-foil), full radiation (PAR+UV$\mathrm{A}+\mathrm{UV}-\mathrm{B}$ ) and darkness. After subsampling for $t_{0}$ measurements, samples were incubated under surface solar radiation at in situ temperature for $6 \mathrm{~h}$. Incubations were made in duplicate; $0.2 \mu \mathrm{m}$ filtered samples served as control. Experiments were performed 4 times with DMSP additions of up to $50 \mathrm{nM}$ (final conc.).

Analysis of DMSP and DMS. Total DMS and DMSP concentrations were determined by putting $20 \mathrm{ml} \mathrm{sam}$ ples into glass vials and adding $2 \mathrm{ml}$ of $5 \mathrm{~N} \mathrm{NaOH}$ (non-degassed sample). For complete alkaline DMSP cleavage to DMS, samples were kept at $4{ }^{\circ} \mathrm{C}$ for $24 \mathrm{~h}$. DMSP concentrations were determined by transferring the samples into glass columns with a glass frit at the lower end and sparging them with nitrogen gas for $20 \mathrm{~min}$. Subsequently the samples were treated as described above. DMS concentrations were calculated as the difference between degassed and non-degassed samples.

DMS analysis was performed using a modified purge and trap system as described elsewhere (Andreae \& Barnard 1983, Kiene \& Service 1991). Volatile sulfur compounds were stripped from the water samples by a stream of nitrogen gas, cryo-trapped in liquid nitrogen and analyzed by gas chromatography (Hewlett Packard Model 5890 Series II, equipped with a flame photometric detector and a Chromosil 330 teflon column, Supelco). Ethylmethylsulfide (EMS, 99\% Aldrich Chemical) served as an internal standard for the analytical system; it was injected in appropriate amounts $(50 \pm 5$ pmol) directly into the bubble chamber and stripped together with the sample. The gas chromatograph was operated isothermally at $70^{\circ} \mathrm{C}$ and at a car-

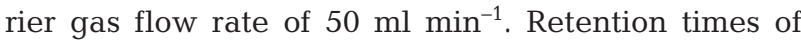
DMS and EMS were 1.2 and $2.1 \mathrm{~min}$, respectively. Calibration was carried out by injecting various amounts of DMS together with $50 \pm 5$ pmol EMS and then relating the ratio of the peak areas of DMS and EMS to the absolute amount of DMS. Standards for DMS and EMS were prepared gravimetrically. Under these conditions the analytical precision was always $>95 \%$.

Rate calculations. The DMSP and DMS removal rate was calculated by taking the linear fit of the time courses of the DMS(P) disappearance according to (Ledyard \& Dacey 1996a) based on at least 4 to 5 measurements beginning at $t_{0}$ (initial removal rate). The initial removal rate in the $0.8 \mu \mathrm{m}$ filtered samples was corrected for the decline in the $0.2 \mu \mathrm{m}$ filtered controls. In one of the experiments, DMSP removal showed hardly any linear decrease; therefore, the first-order rate constant was determined and multiplied with the initial DMSP concentration to calculate the initial DMSP removal rate (see Fig. 1A) (Kiene 1996b). DMS 


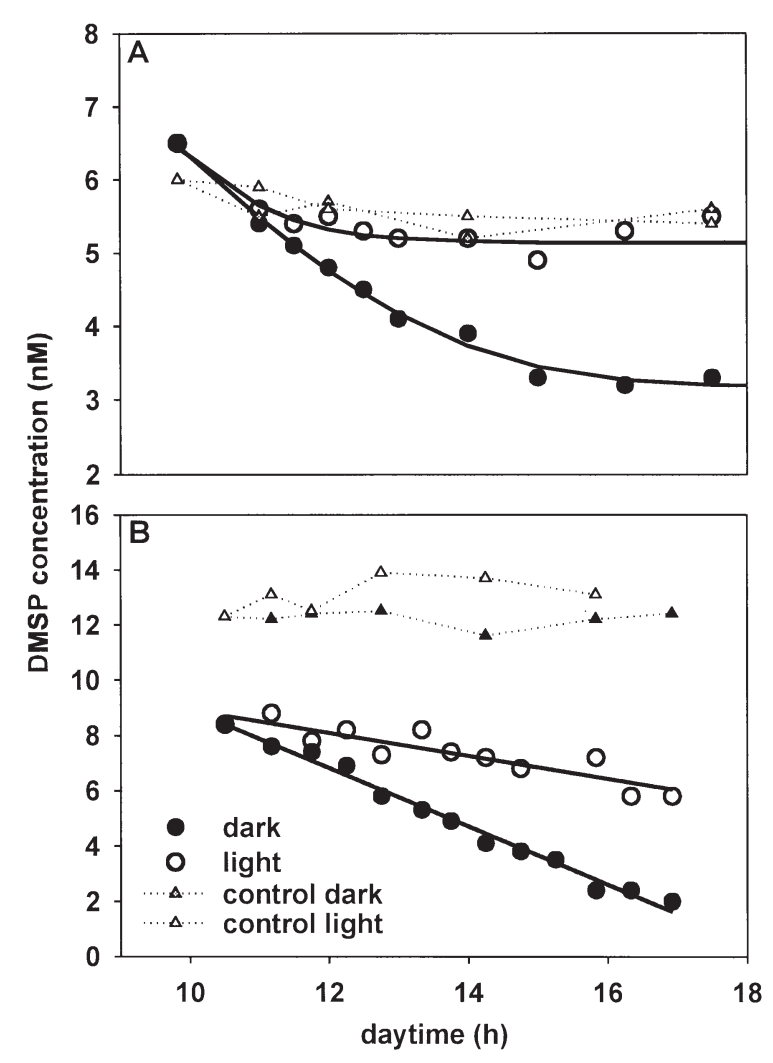

Fig. 1. Effects of surface solar radiation on the kinetic of the biological removal of DMSP in 2 experiments. (A) 17 August 1997, (B) 18 June 1997. Time course of the decline of DMSP in $0.8 \mu \mathrm{m}$ filtered natural seawater in the dark (dark) compared to treatments exposed to the full range of natural solar radiation (light); $0.2 \mu \mathrm{m}$ filtered seawater served as a control. Symbols represent DMSP concentrations measured in single incubations. DMSP decay rates were calculated from the linear fit of the initial DMSP decline (referred to as 'initial DMSP removal rate' in the text); in (A), light treatments, the pseudo first-order rate constant was determined for calculation of the initial removal rate

removal in the $0.8 \mu \mathrm{m}$ filtered radiation-exposed treatments consists of photochemical removal (determined in the $0.2 \mu \mathrm{m}$ filtered radiation-exposed control) and the biological consumption of DMS inhibited by solar radiation. The biotic removal rate due to bacteria was calculated by subtracting the photochemical removal rate from the total removal rate in the corresponding $0.8 \mu \mathrm{m}$ filtered sample.

The photochemical removal rate was calculated by taking the pseudo first-order rate constant as the slope of the plot of the natural log of the DMS concentration versus time (Kieber et al. 1996, Brugger et al. 1998). By multiplying the rate constant with the initial DMS concentration the photochemical removal rate was obtained. Biological and photochemical removal rates were all corrected for the DMS dynamics in the $0.2 \mu \mathrm{m}$ filtered dark control.

\section{RESULTS}

\section{Reduction of the biological DMSP removal by natural surface solar radiation}

In the $0.8 \mu \mathrm{m}$ filtered seawater incubated in the dark, the in situ DMSP concentration decreased due to bacterial removal of DMSP. Initially, the DMSP concentration decreased linearly, in one experiment it leveled off as the DMSP concentrations reached $\sim 3 \mathrm{nM}$ (Fig. 1A). However, another experiment showed a linear decrease throughout the entire incubation period to DMSP concentrations of $\sim 2 \mathrm{nM}$ (Fig. 1B). Exposure to surface solar radiation resulted in a reduction of the initial DMSP removal rate by $\sim 50$ to $60 \%$ over the 6 to $7 \mathrm{~h}$ exposure period as compared to the removal rate in the dark (Fig. 1). In one case (Fig. 1A) DMSP removal rate decreased at a higher DMSP concentration than in the dark treatments.

The potential removal rates measured after DMSP amendments and exposure to natural solar radiation for $7 \mathrm{~h}$ are exemplified in Fig. 2. The initial removal rate in the dark of $7.06 \mathrm{nmol}^{-1} \mathrm{~h}^{-1}$, which leveled off at $\sim 15 \mathrm{nM}$, was reduced by $74 \%$ in the radiation-exposed treatments over the first $4 \mathrm{~h}$ of incubation. In general, DMSP removal rates varied considerably among different experiments and were not related to initial DMSP concentrations (Table 1). Surface solar radiation levels reduced the initial removal rates measured in the dark in almost all experiments by more than $50 \%$; however, the percentage of reduction varied considerably (Table 1).

In the $0.2 \mu \mathrm{m}$ filtered natural seawater no significant difference in DMSP concentration between dark and

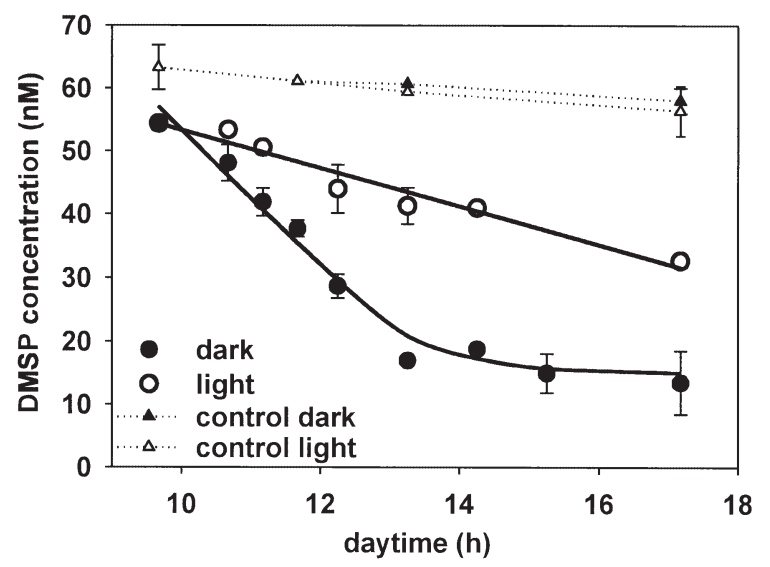

Fig. 2. Example of a time course (obtained 10 July 1997) of the decline in DMSP in $0.8 \mu \mathrm{m}$ filtered seawater under natural solar radiation and in the dark (circles and solid lines), controls of $0.2 \mu \mathrm{m}$ filtered seawater are indicated by triangles and dotted lines. DMSP was added to a final concentration of 55 nM. Symbols are means of duplicate treatments, bars indicate SD 
Table 1. Biological DMSP removal rates in $0.8 \mu \mathrm{m}$ filtered natural seawater exposed to surface solar radiation (BR-rad) compared to biological DMSP removal rates in the dark (BRdark). Samples in 1996 were taken in the northern Adriatic Sea about $5 \mathrm{~km}$ off Ancona, Italy; samples collected in 1997 are from the costal North Sea, Texel, The Netherlands. Asterisks indicate significant difference compared to biological removal rates under dark conditions as determined by Student's $t$-test slope comparison: ${ }^{* * *} \mathrm{p}<0.001,{ }^{* *} \mathrm{p}<0.01$, ${ }^{*} \mathrm{p}<0.05$

\begin{tabular}{|c|c|c|c|}
\hline Date & $\begin{array}{l}\text { Initial DMSP } \\
\text { conc. (nM) }\end{array}$ & $\begin{array}{c}\text { BR-dark } \\
\left(\mathrm{nmol} \mathrm{l}^{-1} \mathrm{~h}^{-1}\right)\end{array}$ & $\begin{array}{r}\text { BR-rad in \% } \\
\text { of BR-dark }\end{array}$ \\
\hline 17 Aug $1997^{a}$ & 6.5 & 0.73 & $40^{* *}$ \\
\hline 18 Jun $1997^{a}$ & 8.4 & 1.05 & $39^{* * *}$ \\
\hline 7 Aug 1997 & 20.7 & 2.73 & $19^{* *}$ \\
\hline 15 Sep 1996 & 28.3 & 1.40 & $25^{* * *}$ \\
\hline 10 Jun 1997 & 29.1 & 2.37 & $38^{* *}$ \\
\hline 25 Sep 1997 & 32.0 & 1.63 & $34^{* *}$ \\
\hline 6 Sep 1996 & 32.7 & 1.40 & $46^{* *}$ \\
\hline 2 Aug 1997 & 33.3 & 2.66 & $71^{*}$ \\
\hline 16 Aug 1997 & 43.0 & 1.23 & $31^{* *}$ \\
\hline 11 Sep 1996 & 46.6 & 2.11 & $48^{*}$ \\
\hline 10 Jul 1997 & 54.4 & 7.06 & $26^{* * *}$ \\
\hline Mean & & 2.3 & 37.9 \\
\hline$\pm \mathrm{SD}$ & & 1.81 & 14.13 \\
\hline
\end{tabular}

radiation-exposed treatments were observed (comparison of slopes with Student's $t$-test ( $p>0.08$; Neter et al. 1996). Free DMSP lyase activity was generally low. Nevertheless, all DMSP removal rates calculated for the $0.8 \mu \mathrm{m}$ filtered seawater were corrected for the activity of free DMSP lyase.

\section{Effect of different initial DMSP concentrations on the inhibition of DMSP removal by surface solar radiation}

In the dark treatments, initial removal rates at various DMSP concentrations usually followed a saturation curve, as shown on one example in Fig. 3A. Under surface solar radiation, the initial removal rates leveled off at significantly lower concentrations than in the dark (Fig. 3A, Wilcoxon, $\mathrm{p}<0.05, \mathrm{n}=5$ ). In Fig. 3B, the initial removal rates at various initial DMSP concentrations are shown, pooled from 3 different experiments. In one experiment, DMSP removal in the dark did not reach saturation at the concentrations applied ( $60 \mathrm{nM})$ and was therefore excluded from the regression analysis. The saturating DMSP concentration of the initial removal rate was significantly lower in radiation-exposed treatments $(\sim 30 \mathrm{nM})$ than in the dark treatments ( $>80 \mathrm{nM}$; Fig. 3B, Wilcoxon, $\mathrm{p}<0.001, \mathrm{n}=$ 28). Nevertheless, the initial DMSP removal rates obtained for different initial DMSP concentrations var- ied considerably between the different dates when experiments were performed. The saturation curve does not follow Michaelis Menten kinetics as checked by linearization using an Eadie Hofstee plot (data not shown).

\section{Reduction of the biological DMSP removal under different radiation regimes}

In a set of experiments, the effect of different wavelength ranges of the solar radiation spectrum was tested. Exposure to the full range of surface solar radiation reduced initial removal rates in $0.8 \mu \mathrm{m}$ filtered natural seawater to $19-71 \%$ of the removal under dark conditions, with UV-B radiation contributing, on average, $15.1 \pm 11.7 \%$ to the total inhibition (Fig. 4). UV-A radiation was responsible, on average,

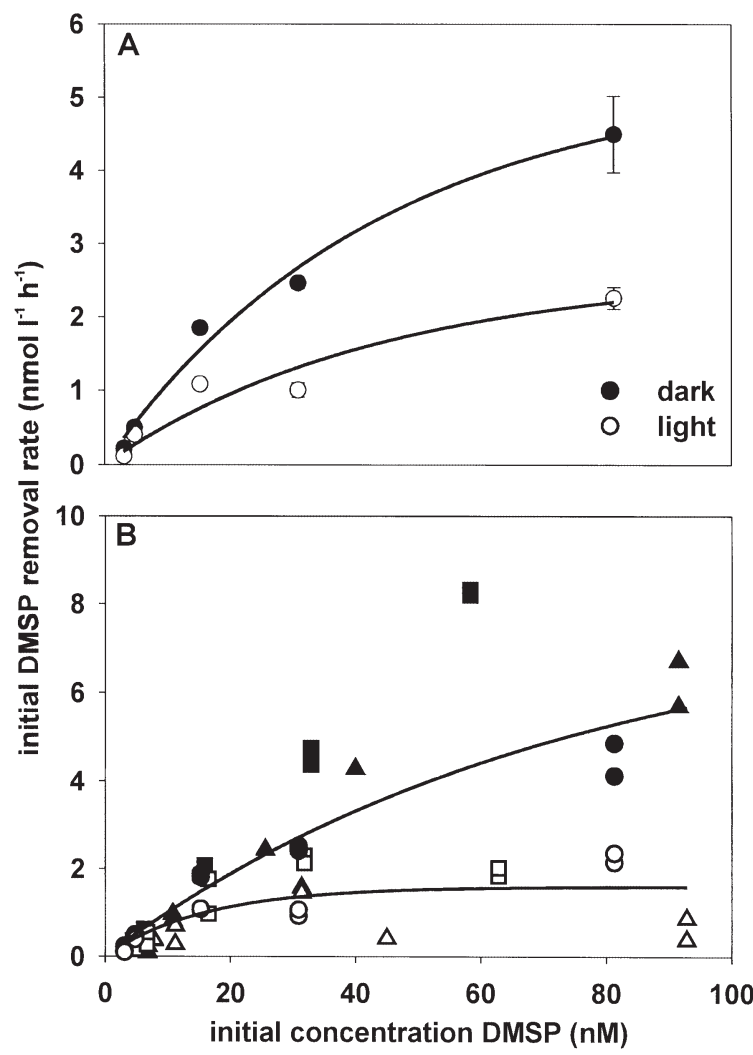

Fig. 3. Dependence of the initial DMSP removal rate on the initial DMSP concentration in $0.8 \mu \mathrm{m}$ filtered seawater under surface solar radiation and in the dark. The initial DMSP removal rate has been corrected for loss obtained in $0.2 \mu \mathrm{m}$ filtered controls. (A) Example for one experiment; symbols are mean of duplicate treatments, bars indicate SD. (B) Three experiments pooled, different symbols indicate the different dates of the experiments. Open symbols represent radiationexposed treatments, solid symbols dark treatments. Solid lines represent exponential fit. Solid squares were excluded from the regression line 
for $42.5 \pm 29.9 \%$, and PAR for $42.4 \pm 32.4 \%$ of total inhibition. High standard deviations are due to the fact that in 2 experiments UV-A was the main inhibitory radiation ( 2 and 16 August), whereas in 2 other experiments the main inhibitory effect was caused by PAR (7 August and 25 September; Fig. 4). In 2 experiments, the contribution of UV-B to the total inhibition effect was rather high (28 and $21 \%$ of total inhibition on 16 August and 25 September, respectively) while in the other 2 experiments UV-B contributed only 1 to $10 \%$.

\section{Reduction of microbial DMS removal in comparison to photochemical removal during exposure to surface solar radiation}

In 4 experiments, the DMS removal due to both photochemical removal and biological consumption was estimated. In $0.2 \mu \mathrm{m}$ filtered seawater, DMS concentrations decreased under surface solar radiation, whereas in the treatment incubated in the dark the DMS concentration increased, probably due to DMSP lyase activity, at a rate of $0.46 \mathrm{nmol} \mathrm{l}^{-1} \mathrm{~h}^{-1}$ (Fig. 5). In the $0.8 \mu \mathrm{m}$ filtered seawater, the DMS concentration in the radiation-exposed treatments decreased at a rate of $0.93 \mathrm{nmol} \mathrm{l}^{-1} \mathrm{~h}^{-1}$, in the dark treatments at a rate of $0.68 \mathrm{nmol} \mathrm{l}^{-1} \mathrm{~h}^{-1}$ (total removal in light and dark was 1.39 and $1.14 \mathrm{nmol} \mathrm{l}^{-1} \mathrm{~h}^{-1}$, respectively, corrected for the $0.2 \mu \mathrm{m}$ filtered dark treatment). By subtracting the photochemical removal rate of $1.02 \mathrm{nmol} \mathrm{l^{-1 }} \mathrm{h}^{-1}$ (derived from the $0.2 \mu \mathrm{m}$ filtered radiation-exposed treatment, corrected for the dark control) from the

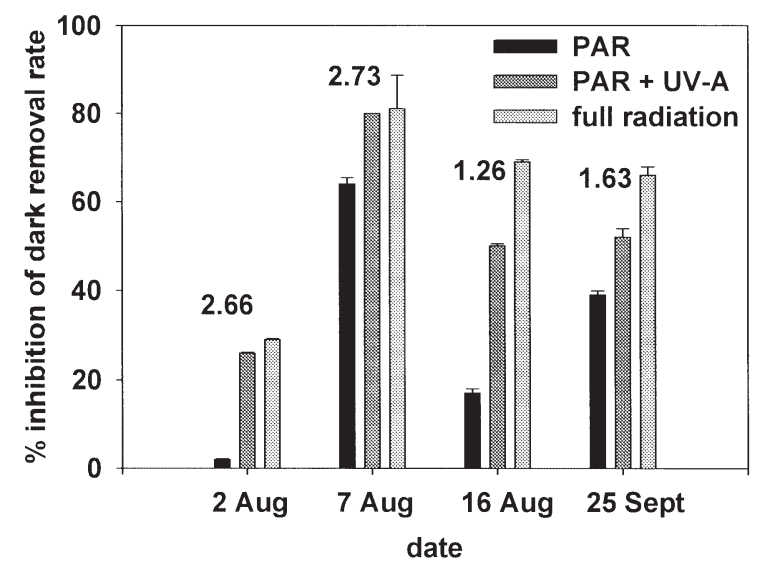

Fig. 4. Contribution of different ranges of natural surface solar radiation to the reduction of biological DMSP removal in $0.8 \mu \mathrm{m}$ filtered seawater (corrected for DMSP removal in $0.2 \mu \mathrm{m}$ filtered controls) as compared to the biological DMSP removal rate in the dark. Numbers above the bars indicate the initial removal rates in the dark treatments in nmol DMSP $\mathrm{l}^{-1} \mathrm{~h}^{-1}$

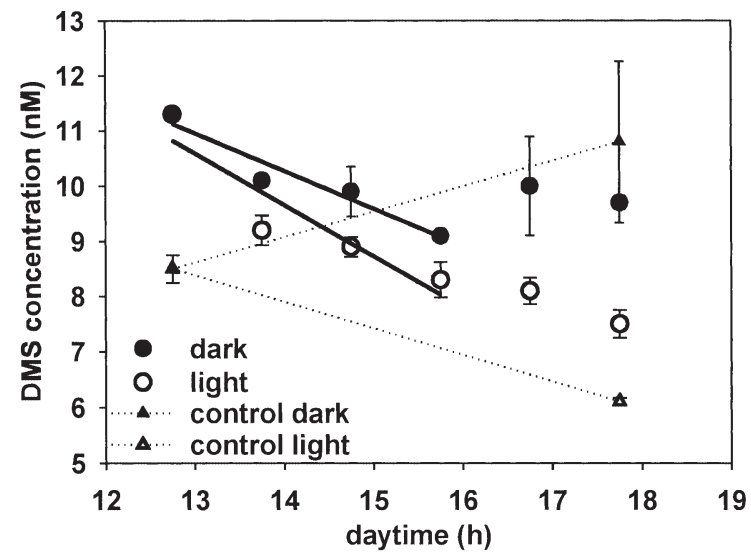

Fig. 5. Time course of the decline of DMS in the dark and under surface solar radiation in $0.8 \mu \mathrm{m}$ filtered natural seawater, in comparison to the DMS decline in $0.2 \mu \mathrm{m}$ filtered seawater exposed to solar radiation (control light) indicating photochemical removal. The control dark treatment was $0.2 \mu \mathrm{m}$ filtered natural seawater kept in the dark by wrapping the flasks in aluminum foil. Symbols are mean of duplicate incubations, bars indicate $\mathrm{SD}$

removal rate determined in the $0.8 \mu \mathrm{m}$ filtered radiation-exposed treatment, we calculated a biological removal rate of $0.37 \mathrm{nmol} \mathrm{l}^{-1} \mathrm{~h}^{-1}$ due to bacterial activity. The rather high free DMSP lyase activity might have come from stimulation through the filtration step, as cells of Phaeocystis sp. which was still rather abundant in June 1997 in the coastal North Sea (G. Cadee pers. comm.) were disrupted. In Table 2 the DMS removal rates under solar radiation are given in comparison to the biological removal rates in the dark and the photochemical DMS removal rates. Bacterial removal of DMS was reduced in the presence of solar radiation to $25-56 \%$ of the biological DMS removal rates under dark conditions. In all experiments, the photochemical removal rate was substantially higher than the bacterial removal under surface solar radiation (Table 2). Only in 1 experiment was DMSP lyase activity high (10 July 1997).

\section{DISCUSSION}

\section{Reduction of the biological DMSP removal by solar surface radiation}

In all experiments except one a clear linear decline in DMSP concentration over time was found for the initial phase of incubation in $0.8 \mu \mathrm{m}$ filtered seawater (Figs 1 \& 2). DMSP removal at in situ concentrations was significantly reduced in all experiments when exposed to surface solar radiation (Fig. 1). Probably, the enzymes of the bacteria present in the samples 
Table 2. Comparison of the biological DMS removal rate in the dark (BRdark), photochemical DMS removal rates (PR), total DMS removal rates under solar radiation (TR-rad) and biological DMS removal rates under solar radiation (BR-rad). BR and TR were determined in $0.8 \mu \mathrm{m}$ filtered seawater, PR in $0.2 \mu \mathrm{m}$ filtered seawater. BR-rad is the difference betweenTR-rad and PR. All rates are given in nmol $\mathrm{l}^{-1} \mathrm{~h}^{-1}$. For sampling locations see Table 1

\begin{tabular}{|c|c|c|c|c|c|}
\hline Date & $\begin{array}{c}\text { Initial DMS } \\
\text { conc. (nM) }\end{array}$ & BR-dark & $\begin{array}{l}\text { PR } \\
\text { (nmo }\end{array}$ & $\begin{array}{l}\text { TR-rad } \\
\left.\mathrm{h}^{-1}\right)\end{array}$ & BR-rad \\
\hline 10 Jun $1997^{a}$ & 8.5 & 1.10 & 1.02 & 1.39 & 0.37 \\
\hline 15 Sep $1996^{a}$ & 10.5 & 0.91 & 0.64 & 1.15 & 0.51 \\
\hline 11 Sep $1996^{a}$ & 25.0 & 1.47 & 1.53 & 1.90 & 0.36 \\
\hline 5 Aug 1997 & 34.6 & 1.16 & 2.08 & 2.63 & 0.55 \\
\hline Mean & & 1.16 & 1.32 & 1.77 & 0.45 \\
\hline$\pm \mathrm{SD}$ & & 0.23 & 0.63 & 0.65 & 0.10 \\
\hline
\end{tabular}

From this kind of experiment the turnover rate can be calculated by multiplying the removal rate with the in situ concentration according to Kiene (1996b). Exposure to natural surface solar radiation resulted in significantly reduced DMSP removal rates ranging between 29 and $81 \%$ of the DMSP removal in the dark (mean $62.1 \pm$ $14.1 \%$, Table 1); hence the turnover will be affected to the same extent. Absolute turnover rates could not be calculated, as the in situ concentrations were not always determined. In the $0.2 \mu \mathrm{m}$ filtered controls no difference in the decline of DMSP was observed between the radiation-exposed and dark treatments, implying that free DMSP lyase was not affected. However,

were photochemically degraded by solar radiation (see Müller-Niklas et al. 1995). In some of the DMSP removal experiments, DMSP removal ceased well before the DMSP was completely depleted. This pattern has been observed previously, mostly for unfiltered but also for filtered seawater (Kiene 1996a,b). In our case we used filtered water; therefore algae were excluded. Since no autofluorescent particles were present in our samples, DMSP production by autotrophs can be excluded. Possibly, bacteria containing DMSP and releasing it during the incubation period are responsible for this effect. Exposure to solar radiation might enhance the release, thereby causing the observed decrease in the DMSP removal rate at higher DMSP concentrations in experiment in Fig 1A.

Generally, we calculated the removal rates according to Ledyard \& Dacey (1996a) because the linear decline indicates that there are no interfering feedback mechanisms. Data points were used for calculation as long as they showed a linear relationship; however, at least the first 4 to 5 sampling points were used. For the data shown in Fig. 1A, the decline in DMSP was not linear. We therefore calculated the rates for the radiation-exposed incubations according to Kiene (1996b) by determining the first-order rate constant and multiplying it with the initial DMSP concentration. For the dark incubations both ways of calculation resulted in essentially the same rate $\left(0.72\right.$ and $0.73 \mathrm{nmol} \mathrm{l}^{-1} \mathrm{~h}^{-1}$, for first and zero orders, respectively). In general, calculating the DMSP removal rates by applying first-order rate constants resulted in slightly higher initial removal rates $(<15 \%)$; however, in 2 cases the differences were $>60 \%$. The percent inhibition remained rather constant except for the latter 2 cases.

In order to determine the potential DMSP removal rate, we performed experiments with additions of DMSP and followed the decline in DMSP concentrations under surface solar radiation and in the dark. free DMSP lyase activity in our experiments was generally rather low; therefore a significant difference between light and dark treatments could remain obscure. Scarratt et al. (1999) also found that free DMSP lyase activity accounted for only $2 \%$ of total DMSP cleavage. In the only case with higher DMSP lyase activity (10 June 1997, Fig. 5) no difference was detected between solar radiation and dark treatments; however these are too few data to exclude any effect of solar radiation on free DMSP lyase activity. Dissolved DMSP added to autoclaved, natural seawater remained stable under exposure to solar radiation (data not shown). Therefore, photochemical DMSP cleavage did not occur as was previously suggested by Hefu \& Kirst (1997).

In the experiments to determine the dependence of the biologically mediated DMSP removal rates on the initial DMSP concentration, the saturating DMSP concentration was significantly lower in the radiationexposed treatments than in the dark (Fig. 3A). These findings indicate that even if DMSP removal is stimulated by, for example, a sudden release of DMSP by phytoplankton exposed to UV radiation the inhibition will increase with increasing DMSP concentration. There was a remarkable consistency within the treatments collected at a single date, but considerable variability between different sampling dates was observed; one case even showed no saturation at all (Fig. 3B). Despite the high variability among sampling dates the general trend of a significantly lower saturation concentration in radiation-exposed treatments was always observable.

A high spatial and temporal variability of the DMSP removal was also shown by Kiene (1996b), Ledyard \& Dacey (1996a,b), Simó \& Pedrós-Alió (1999), Scarratt et al. (2000), and Schultes et al. (2000). Kiene (1996b) determined the turnover of DMSP in estuarine and shelf waters and found highly variable turnover rates with no 
discernable distinct seasonal pattern. Ledyard \& Dacey (1996b) examined turnover, uptake and lyase kinetics of DMSP in coastal waters and also found high spatial and temporal variability, as observed in this study. Scarratt et al. (2000) investigated the kinetics of the potential DMS production from DMSP cleavage in North Atlantic waters and found an inverse exponential relation to chl a concentrations. Besides the high short-term variability of rates, Simó \& Pedrós-Alió (1999) further found that coupling and decoupling of DMSP consumption, DMS production and DMS consumption occurred on very short time scales within the water body of an eddy. Within a few days, DMS production accounted for $100 \%$ to only $6 \%$ of the DMSP consumed.

In addition to the high variability in DMSP dynamics reported previously, the present study clearly shows that the reduction in DMSP removal rate upon exposure to surface solar radiation also varies considerably. Variations in the intensity and in the ratios of different wavelength regimes of solar radiation might be a possible explanation for the observed variability, although all our experiments were performed under a cloudless sky. Unfortunately irradiation measurements are not available for all the experiments that were conducted, but the ratios between UV-B, UV-A and PAR from 6 to 8 August 1997 only varied by $<5 \%$ and the daily integrated radiation over this period also varied by $<5 \%$ (J. H. Vosjan pers. comm.). On 7 August, the biological removal of DMSP (20.7 nM initial concentration) in radiation-exposed treatments was inhibited by $81 \%$ as compared to the removal rate in the dark (Table 1). From the saturation experiment on the 6 and 8 August (triangles and squares, respectively; Fig. 3B), we calculated the removal rates for radiation-exposed and dark treatments for the same concentration by applying an exponential or linear fit to the data obtained for each day (as in the example in Fig. 3A). Inhibition of the removal rates in radiation-exposed treatments accounted for 62 and $51 \%$ of the removal in the dark for 6 and 8 August, respectively. Obviously total radiation and the ratios of UV-B to PAR or UV-A were not

Table 3. Bacterial production (BSP) and DMSP removal by bacteria (BR) in dark and radiation-exposed treatments determined in $0.8 \mu \mathrm{m}$ filtered natural seawater. BSP was measured by the incorporation of tritiated leucine $\left(\left[{ }^{3} \mathrm{H}\right]\right.$ leucine) for $30 \mathrm{~min}$ immediately after exposure to solar radiation. Samples were taken from the northern Adriatic Sea about $5 \mathrm{~km}$ off Ancona, Italy

\begin{tabular}{|lcccc|}
\hline Date & $\begin{array}{c}\text { BSP-dark } \\
\left(\mu \mathrm{g} \mathrm{C} \mathrm{l}^{-1} \mathrm{~d}^{-1}\right)\end{array}$ & $\begin{array}{c}\text { BSP-rad in \% } \\
\text { of BSP-dark }\end{array}$ & $\begin{array}{c}\text { BR-dark } \\
\left(\mathrm{nmol} \mathrm{l}^{-1} \mathrm{~h}^{-1}\right)\end{array}$ & $\begin{array}{c}\text { BR-rad in \% } \\
\text { of BR-dark }\end{array}$ \\
\hline 6 Sep 1996 & 0.51 & 41 & 1.4 & 46 \\
11 Sep 1996 & 0.47 & 13 & 2.11 & 48 \\
15 Sep 1996 & 0.73 & 19 & 1.40 & 25 \\
\hline
\end{tabular}

responsible for the differences observed in the inhibition of the bacteria involved in DMSP removal.

The composition of the bacterial community might be of major importance in determining the variability of DMSP removal. Arrieta et al. (2000) demonstrated that bacterial strains are highly variable in their sensitivity to UV radiation and in their ability to recover from previous UV stress. Additionally, differences in DMSP lyase expression among different members of the bacterial community might enhance the observed variations in biological DMSP removal rates and their reduction due to exposure to solar radiation. On 3 occasions bacterial production as a general activity parameter was determined by the incorporation of $\left[{ }^{3} \mathrm{H}\right]$ leucine (according to Kirchman et al. 1985) for the experiments performed in the Mediterranean Sea. In Table 3 the bacterial production and DMSP removal in the dark are listed; in addition, the percent inhibition after exposure to surface solar radiation is given. From our few experiments we conclude that absolute DMSP removal was not coupled to the amount of bacterial production, which is in contrast to findings of Kiene \& Linn (2000), who report a close relation between DMSP turnover and bacterial production in oceanic and shelf regions of the Gulf of Mexico. Furthermore, the degree of inhibition differed between bacterial production and DMSP removal (Table 3), indicating that these 2 metabolic processes were affected differently by solar radiation in the Mediterranean Sea.

\section{Influence of different radiation ranges on biological DMSP removal rates}

Radiation-induced inhibition in the metabolic activity and damage of organisms in aquatic systems was previously thought to be largely mediated by UV-B radiation. There is evidence accumulating now, however, that UV-A contributes the same or even a larger extent to the inhibition of activity (Bailey et al. 1983, Sieracki \& Sieburth 1986, Herndl et al. 1997, Sommaruga et al. 1997, Visser et al. 1999). Our experiments reveal that UV-B radiation contributes, on average, $\sim 15 \%$ to the observed total reduction of DMSP removal rate, whereas UV-A and PAR each contribute $\sim 42 \%$ to the total inhibition (Fig. 4). In 2 experiments, PAR radiation caused the main inhibitory effect; in 2 other experiments UV-A was responsible for most of the inhibition (Fig. 4). Sieracki \& Sieburth (1986) showed that UV-A radiation was mainly responsible for the observed growth delay of marine bacteria, whereas PAR did not cause any inhibition. Other authors could also attribute a small inhibitory effect on bac- 
terial activity to PAR radiation (Bailey et al. 1983, Sommaruga et al. 1997, Visser et al. 1999). In a study performed in the Gulf of Mexico, Aas et al. (1996) showed that there was no consistent response pattern in bacterial activity to different wavelength ranges, consistent with our results on DMSP removal.

The fact that longer wavelengths (UV-A and PAR) are mainly responsible for the inhibition of biological processes implies that removal rates of DMSP can be affected to considerable depths in the oceanic water column. Obernosterer et al. (2001) found that biologically and photochemically effective UV radiation penetrates to depths of $\sim 60 \mathrm{~m}$ in the open subtropical Atlantic, which comprises about half of the euphotic layer (Obernosterer et al. 2001). As turnover and removal rates of DMSP have always been determined in samples incubated in the dark (Kiene 1996b, Ledyard \& Dacey 1996a,b), the removal rates of DMSP reported in previous studies have to be considered as maximum estimates. The actual biological DMSP removal rates in the upper layers of the ocean are probably lower due to partial inhibition of DMSP removal by solar radiation.

\section{Biological versus photochemical DMS removal}

The experiments conducted to compare biological with photochemical DMS removal clearly show that biological removal of DMS is inhibited, on average, by $59.6 \pm 14.0 \%$ (Table 2). Photochemical removal rates were determined by assuming pseudo first-order kinetics (Kieber et al. 1996, Brugger et al. 1998). Bacterial DMS removal under solar radiation is substantially lower than photochemical DMS removal when exposed to surface radiation levels (Table 2). Kieber et al. (1996) investigated the relation between photochemical and biological DMS removal and atmospheric ventilation but incubated the treatments to estimate the biological DMS removal in the dark. The authors compared the biological DMS removal to photochemical removal and loss via atmospheric ventilation in different layers of the euphotic zone. In 5 out of 8 experiments, biological removal exceeded the photochemical removal in the 0 to 1 and 0 to $20 \mathrm{~m}$ surface layers (Kieber et al. 1996). The present study suggests, however, that inhibition of the removal of DMS by bacteria and the photochemical removal might be high in the first few meters during daytime. Furthermore, the total DMS removal rate under surface solar radiation (biological and photochemical) measured in different environments always exceeded the biological removal rate in the dark, indicating that in the first few meters DMS concentrations decline at a higher rate during the day than in the night. In deeper layers, where solar radia- tion is increasingly attenuated, the photochemical effect will decline exponentially (Kieber et al. 1996) and the biological removal will approach rates obtained in dark incubation. Simó \& Pedrós-Alió (1999) estimated the photochemical DMS removal by subtracting the calculated DMS concentration (from the DMSP and DMS consumption and the DMS production rates) from the measured in situ DMS concentration. Again these rates were determined in dark incubations; therefore the photochemical DMS removal might be underestimated for the near-surface layers.

We did not distinguish between DMSP cleavage and demethylation. If we assume, in a rough estimate, that bacterial cleavage and demethylation processes are affected by solar radiation at approximately the same rate, on average, about $60 \%$ less DMS would evolve from DMSP cleavage in our radiation-exposed treatments (Table 1). The lower amount of DMS ready for consumption in radiation exposed bottles increases the differences from the dark treatments; therefore, the reduction of the biological DMS removal would be underestimated by a factor of approximately 1.6 (derived from the calculation of 100/60).

The impact of solar radiation on the bacterial removal of DMSP and DMS has received surprisingly little attention despite intense research on the effect of UV radiation on organisms. In our study, surface radiation intensities were chosen, which implies that our results represent the upper limit of what can be expected in nature.

\section{CONCLUSIONS}

In our study we demonstrated that the biological removal of both DMS and DMSP is reduced by 60\% of the dark removal rates due to natural surface solar radiation. High spatial and temporal variability of the removal rates in the dark, but also their sensitivity to solar radiation, was observed. The responsible wavelength ranges for inhibiting DMS and DMSP removal are mainly UV-A and PAR, while UV-B contributes only $\sim 15 \%$ to the total radiation-mediated inhibition. Consequently, DMS and DMSP turnover is considerably reduced by solar radiation in the upper mixed layer of the oceanic water column, possibly down to a depth of $\sim 60 \mathrm{~m}$. Photochemical DMS removal is higher than the biological DMS removal under solar radiation in the near-surface water layers.

Acknowledgements. The authors want to thank Roberto Danovaro and Mauro Fabiano for providing laboratory space during the field work at the Institute of Marine Biology and Biochemistry, University of Ancona, as well as the colleagues at the NIOZ, Texel, for all their help. Especially we thank E. 
Lorbeer for his invaluable help in establishing the analytical method. We thank Ingrid Obernosterer for help with the radiation data and 2 anonymous reviewers for helpful comments on an earlier version of the manuscript. Financial support was provided by a grant from the Austrian Science Foundation (Fond zur Foerderung der wissenschaftlichen Forschung, FWF project no. 9388) and by the Environment \& Climate Program of the European Community (Microbial community response to UV-B stress in European Waters, project no. EV5V-CT94-0512). This work is part of the fulfillment of the requirements towards a $\mathrm{PhD}$ degree at the University of Vienna for D.S. This is contribution no. 3621 of the NIOZ.

\section{LITERATURE CITED}

Aas P, Lyons MM, Pledger R, Mitchell DL, Jeffrey WH (1996) Inhibition of bacterial activities by solar radiation in nearshore waters and the Gulf of Mexico. Aquat Microb Ecol 11:229-238

Andreae MO (1990) Ocean-atmosphere interactions in the global biochemical cycle. Mar Chem 30:1-29

Andreae MO, Barnard WR (1983) Determinations of trace quantities of dimethyl sulfide in aqueous solutions. Anal Chem 55:608-612

Andreae MO, Raemdonck H (1983) Dimethyl sulfide in the surface ocean and the marine atmosphere: a global view. Science 221:744-747

Arrieta JM, Weinbauer MG, Herndl GJ (2000) Interspecific differences in the sensitivity to ultraviolet radiation and subsequent recovery in selected isolates of marine bacteria. Appl Environ Microbiol 66:1468-1473

Ayers GP, Ivey JP, Gillett RW (1991) Coherence between seasonal cycles of dimethylsulphide, methanesulphonate and sulphate in marine air. Nature 349:404-406

Bailey CA, Neihof RA, Tabor PS (1983) Inhibitory effects of solar radiation on amino acid uptake in Chesapeake Bay bacteria. Appl Environ Microbiol 46:44-49

Barnard WR, Andreae MO, Watkins WE (1982) The flux of dimethylsulfide from the oceans to the atmosphere. J Geophys Res 87:8787-8793

Benner R, Biddanda B (1998) Photochemical transformation of surface and deep marine dissolved organic matter: effects on bacterial growth. Limnol Oceanogr 43:1373-1378

Berresheim H (1993) Distribution of atmospheric sulphur species over various wetland regions in the southeastern U.S.A. Atmos Environ 27:211-221

Blumthaler M, Ambach W (1990) Indication of increasing solar ultraviolet-B radiation flux in Alpine regions. Science 248:206-208

Brimblecombe P, Shooter D (1986) Photo-oxidation of dimethylsulphide in aqueous solution. Mar Chem 19:343-353

Brugger A, Slezak D, Obernosterer I, Herndl GJ (1998) Photolysis of dimethyl sulfide in coastal waters: dependence on substrate concentration, irradiance and DOC concentration. Mar Chem 59:321-331

Cantoni GL, Anderson DG (1956) Enzymatic cleavage of dimethylpropiothetin by Polysiphonia lanosa. J Biol Chem 222:171-177

Charlson RJ, Lovelock JE, Andreae MO, Warren SG (1987) Oceanic phytoplankton, atmospheric sulphur, cloud albedo and climate. Nature 326:655-661

Cooper WJ, Lean DRS (1989) Hydrogen peroxide concentration in a northern lake: photochemical formation and diel variability. Environ Sci Technol 23:1425-1428

Crutzen PJ (1992) Ultraviolet on the increase. Nature 356: 104-105
Gieskes WWC, Kraay GW (1990) Transmission of ultraviolet light in the Weddell Sea: report of the first measurements made in the Antarctic. Biomass Newslett 12:12-14

Graneli W, Lindell M, Tranvik L (1995) Photooxidation of dissolved organic matter in lakes of different humic content. Limnol Oceanogr 41:698-706

Hefu Y, Kirst GO (1997) Effect of UV-radiation on DMSP content and DMS formation of Phaeocystis antarctica. Polar Biol 18:402-409

Herndl GJ, Müller-Niklas G, Frick J (1993) Major role of ultraviolet-B in controlling bacterioplankton growth in the surface layer of the ocean. Nature 361:717-719

Herndl GJ, Brugger A, Hager S, Kaiser E, Obernosterer I, Reitner B, Slezak D (1997) Role of ultraviolet-B radiation on bacterioplankton and the availability of dissolved organic matter. Plant Ecol 128:42-51

Jeffrey WH, Pledger RJ, Aas P, Hager S, Coffin RB, Haven RV, Mitchell DL (1996) Diel and depth profiles of DNA photodamage in bacterioplankton exposed to ambient solar ultraviolet radiation. Mar Ecol Prog Ser 137:283-291

Keller MD, Bellows WK, Guillard RRL (1989a) Dimethyl sulfide production in marine phytoplankton. In: Saltzman ES, Cooper WJ (eds) Biogenic sulfur in the environment. American Chemical Society, Washington, DC, p 167-182

Keller MD, Bellows WK, Guillard RRL (1989b) Dimethylsulfide production and marine phytoplankton: an additional impact of unusual blooms. In: Cosper EM, Bricelj VM, Carpenter EJ (eds) Novel phytoplankton blooms. Springer-Verlag, Heidelberg, p 101-115

Kerr JB, McElroy CT (1993) Evidence for large upward trends of ultraviolet-B radiation linked to ozone depletion. Science 262:1032-1034

Kieber DJ, Jiao J, Kiene RP, Bates TS (1996) Impact of dimethylsulfide photochemistry on methyl sulfur cycling in the equatorial Pacific Ocean. J Geophys Res 101:C2, 3715-3722

Kiene RP (1990) Dimethyl sulfide production from dimethylsulfoniopropionate in coastal seawater samples and bacterial cultures. Appl Environ Microbiol 56(11):3292-3297

Kiene RP (1996a) Production of methanethiol from dimethylsulfoniopropionate in marine surface waters. Mar Chem 54:69-83

Kiene RP (1996b) Turnover of dissolved DMSP in estuarine and shelf waters from the Northern Gulf of Mexico. In: Kiene RP, Visscher P, Keller M, Kirst G (eds) Biological and environmental chemistry of DMSP and related sulfonium compounds. Plenum, New York, p 337-349

Kiene RP, Bates TS (1990) Biological removal of dimethyl sulphide from sea water. Nature 345:702-705

Kiene RP, Linn LJ (2000) Distribution and turnover of dissolved DMSP and its relationship with bacterial production and dimethylsulfide in the Gulf of Mexico. Limnol Oceanogr 45:849-861

Kiene RP, Service SK (1991) Decomposition of dissolved DMSP and DMS in estuarine waters: dependence on temperature and substrate concentration. Mar Ecol Prog Ser 76:1-11

Kirchman D, K'Ness E, Hodson R (1985) Leucine incorporation and its potential as a measure of protein synthesis by bacteria in natural aquatic systems. Appl Environ Microbiol 49:599-607

Ledyard KM, Dacey JWH (1994) Dimethylsulfide production from dimethylsulfoniopropionate by a marine bacterium. Mar Ecol Prog Ser 110:95-103

Ledyard KM, Dacey JWH (1996a) Kinetics of DMSP-lyase activity in coastal seawater. In: Kiene RP, Visscher P, Keller M, Kirst G (eds) Biological and environmental chemistry of 
DMSP and related sulfonium compounds. Plenum, New York, p 325-335

Ledyard KM, Dacey JWH (1996b) Microbial cycling of DMSP and DMS in coastal and oligotrophic seawater. Limnol Oceanogr 41:33-40

Lee C, Wakeham SG (1992) Organic matter in the water column: future research challenges. Deep-Sea Res 39:95-118

Liss PS (1973) Processes of gas exchange across an air-water interface. Deep-Sea Res 20:221-238

Liss PS, Hatton AD, Malin G, Nightingale PD, Turner SM (1997) Marine sulfur emissions. Phil Trans R Soc Lond B 352:159-169

Lyons MM, Aas P, Pakulski JD, Waasbergen LV, Miller RV, Mitchell DL, Jeffrey WH (1998) DNA damage induced by ultraviolet radiation in coral-reef microbial communities. Mar Biol 130:537-543

Mopper K, Zhou X, Kieber RJ, Kieber DJ, Sikorski RJ, Jones RD (1991) Photochemical degradation of dissolved organic carbon and its impact on the oceanic carbon cycle. Nature 353:60-62

Moran MA, Zepp RG (1997) Role of photoreactions in the formation of biologically labile compounds from dissolved organic matter. Limnol Oceanogr 42:1307-1316

Müller-Niklas G, Heissenberger A, Puskaric S, Herndl GJ (1995) Ultraviolet-B radiation and bacterial metabolism in coastal waters. Aquat Microb Ecol 9:111-116

Neter J, Cutner MH, Nachtsheim CJ, Wasserman W (1996) Applied linear statistical models. Irvin, Chicago

Nguyen BC, Bonsang B, Gaudry A (1983) The role of the ocean in the global atmospheric sulfur cycle. J Geophys Res 88:10903-10914

Obernosterer I, Herndl GJ (2000) Differences in the optical and biological reactivity of the humic and nonhumic dissolved organic carbon component in two contrasting coastal marine environments. Limnol Oceanogr 45: $1120-1129$

Obernosterer I, Reitner B, Herndl GJ (1999) Contrasting effects of solar radiation on dissolved organic matter and its bioavailability to marine bacterioplankton. Limnol Oceanogr 44:1645-1654

Obernosterer I, Ruardij P, Herndl GJ (2001) Spatial and diurnal dynamics of DOM fluorescence and $\mathrm{H}_{2} \mathrm{O}_{2}$ and the photochemical oxygen demand of surface water DOM across the subtropical Atlantic Ocean. Limnol Oceanogr 46:632-643

Osinga R, Kwint RLJ, Lewis WE, Kraay GW, Lont JD, Lindeboom HJ, van Duyl FC (1996) Production and fate of dimethylsulfide and dimethylsulfoniopropionate in pelagic mesocosms: the role of sedimentation. Mar Ecol Prog Ser 131:275-286

Palenik B, Price NM, Morel FMM (1991) Potential effects of UV-B on the chemical environment of marine organisms: a review. Environ Pollut 70:117-130

Pausz C, Herndl GJ (1999) Role of ultraviolet radiation on phytoplankton extracellular release and its subsequent

Editorial responsibility: John Dolan,

Villefranche-sur-Mer, France utilization by marine bacterioplankton. Aquat Microb Ecol 18:85-93

Prospero JM, Savoie DL, Saltzman ES, Larsen A (1991) Impact of oceanic sources of biogenic sulfur on sulfate aerosol concentrations at Mawson, Antarctica. Nature 350: 221-223

Sakka A, Gosselin M, Levasseur M, Michaud S, Monfort P, Demers S (1997) Effects of reduced ultraviolet radiation on aqueous concentrations of dimethylsulfoniopropionate and dimethylsulfide during a mesocosm study in the Lower St. Lawrence estuary. Mar Ecol Prog Ser 149:227-238

Scarratt M, Cantin G, Levasseur M, Michaud S (1999) Particle size-fractionated kinetics of DMS production: where does DMSP cleavage occur at the microscale. J Sea Res 43: 245-252

Scarratt M, Levasseur M, Schultes S, Michaud S, Cantin G, Vezina A, Gosselin M, de Mora SJ (2000) Production and consumption of dimethylsulfide (DMS) in North Atlantic waters. Mar Ecol Prog Ser 204:13-26

Schultes S, Levasseur M, Michaud S, Cantin G, Wolfe G, Gosselin M, de Mora S (2000) Dynamics of dimethylsulfide production from dissolved dimethylsulfoniopropionate in the Labrador Sea. Mar Ecol Prog Ser 202:27-40

Sieracki ME, Sieburth JM (1986) Sunlight-induced growth delay of planktonic marine bacteria in filtered seawater. Mar Ecol Prog Ser 33:19-27

Simó R, Pedrós-Alió C (1999) Short-term variability in the open ocean cycle of dimethylsulfide. Global Biogeochem Cycles 13:1173-1181

Smith RC, Prézelin BB, Baker KS, Bidigare RR, Boucher NP, Coley T, Karentz D, McIntyre S, Matlick HA, Menzies D, Ondrusek M, Wan Z, Waters KJ (1992) Ozone depletion: ultraviolet radiation and phytoplankton biology in Antarctic waters. Science 255:952-959

Sommaruga R, Obernosterer I, Herndl GJ, Psenner R (1997) Inhibitory effect of solar radiation on thymidine and leucine incorporation by freshwater and marine bacterioplankton. Appl Environ Microbiol 63:4178-4184

Tranvik L, Kokalj S (1998) Decreased biodegradability of algal DOC due to interactive effects of UV radiation and humic matter. Aquat Microb Ecol 14:301-307

Vairavamurthy A, Andreae MO, Iverson RL (1985) Biosynthesis of dimethylsulfide and dimethylpropiothetin by Hymenomonas carterae in relation to sulfur source. Limnol Oceanogr 30(1):59-70

Visser PM, Snelder E, Kop AJ, Boelen P, Buma AGJ, van Duyl FC (1999) Effects of UV radiation on DNA photodamage and production in bacterioplankton in the coastal Caribbean Sea. Aquat Microb Ecol 20:49-58

Zafiriou OC, Joussot-Dubien J, Zepp RG, Zika RG (1984) Photochemistry of natural waters. Environ Sci Technol 18: 358-371

Zepp RG, Callaghan TV, Erickson DJ (1995) Effects of increased solar ultraviolet radiation on biogeochemical cycles. Ambio 24:181-187

Submitted: December 1, 2000; Accepted: May 2, 2001

Proofs received from author(s): July 17, 2001 